\title{
The Role of Business Ethics in the Relationship between Market Orientation and Business performance
}

\author{
Gusti O. Widanal, Sudarso K. Wirjono, Mustika S. Purwanegara and Mohamad Toha \\ The School of Business Management, Intitut Teknologi Bandung, Indonesia
}

\begin{abstract}
The positive of impact of market orientation toward business performance of a company is a common wisdom in the marketing literatures. Hence the prior studies recommend that the connection will depend on other strategic actions. In this regards, this study tries to assess the construct of business ethics as the precedent of market orientation in the context of Indonesia Islamic banks. Upon assessing data using SmartPLS, this study finds that market orientation is the determinant of business performance and Islamic business ethics is the precedent of market orientation. However, market orientation is not effective as the mediator in the relationship between Islamic business ethics and business performance. The discussion of this finding is provided as well as the managerial implication at the end of this paper.
\end{abstract}

Key words: Business ethics; market orientation, Islamic business ethics, Islamic banking, business performance JEL code: M31, G21

(C) 2015 Published by SSBFNET

\footnotetext{
${ }^{1}$ For all correspondence contact to the first author at gusti.ngurah@sbm-itb.ac.id
} 


\section{Introduction}

Understanding the determinants of business performance is a central aim of the management scholars. For few decades, the market orientation concept has given researchers' understanding of the relationship between the companies' strategy and business performance (Kirca et al., 2005). The perspective of market orientation is established on the assumption that companies will increase and maintain their advantage by serving the main stakeholders effectively and meeting the needs of the market constantly (Narver \& Slater, 1990).

Despite of many previous studies have published strong argumentations to prove the positive connection between a market oriented company and its business performance (Kirca et al., 2005), but not until recently the scholars have contended that the relationship between market orientation and company's performance has been a result of relationship among number of strategic actions, which still wide open to explore (Olavarrieta \& Friedmann, 2008). Zhou et al. (2008, p. 985) described "simply assessing the direct link between market orientation and performance is not fruitful'". Responding to this indication, this study seeks to assess the interaction among business ethics, market orientation and business performance.

This study takes Islamic banking as a research context because the importance of business ethics implementation in its operation. Islamic bank is an modern bank institution which its operation is strictly in accordance with Islamic law (syariah) based on Al Quran and Sunna (deed, talked and action of prophet Muhammad) (Van Schaik, 2001). Whereby, Al Quran and Sunna underline the importance of the implementation of good ethical conducts in all aspects of human life, including business. Still, the implementation of ethics in the business of Islamic banks explicitly is questionable (Wilson, 2005).

The study of market orientation in Islamic bank is very rare, either the study of how market orientation and business ethics interact each other. Thus, the objective of this study is also filling this research gap.

To achieve the aforementioned objective, this paper starts with literature review and hypothesis development on the relationship of market orientation and business performance, the relationship Islamic business ethics and business performance, the review regarding business performance in Islamic banking, the research methodology, discussion and managerial implication. The conclusion, as well as limitation and the opportunity of future research is given at the end of this paper.

\section{Literature Review and Hypotheses Development}

\subsection{Market orientation and Performance}

As early as the 1950s, McKitterick (1958) revealed the importance of responsiveness to stakeholders' needs, management the competitive landscape, and coordination the internal activities for companies to gain superior performance. Recently, the scholars viewed market orientation as key potential to alter the company's resources into superior performance (Hult et al., 2005; Zhou et al., 2008). In the literature, there is common wisdom that market orientation has a positive impact on business performance, including financial performance (Day, 1994; Han et al., 1998; Kirca et al., 2005; Ellis, 2006; Kohli \& Jaworski, 1990; Narver \& Slater, 1990), customer satisfaction and retention (Narver \& Slater, 1990), and employee commitment (Matsuno et al., 2002).

Two publications being considered having seminal contribution to the development of market orientation are from Kohli \& Jaworski (1990) and Narver \& Slater (1990). These two publications are the first attempts to define market orientation, develop scales for measuring the construct, and formulate the link of market orientation to business performance (Van Raaij \& Stoelhorst, 2008). 
Kohli \& Jaworski (1990) posited that the market orientation entails the implementation of the marketing concept, meaning being customer-focused and direct to all marketing activities towards profitability. Narver \& Slater (1990) said that market orientation was the organizational culture that cultivates the required behaviors in most effective and efficient way to produce superior value for customers.

The conceptualization of market orientation from Kohli \& Jaworski (1990) is called as MARKOR, while from Narver \& Slater (1990) is MKTOR. Both MARKOR and MKTOR have become a benchmark for later scholars in conducting market orientation studies and have been widely used either in their original form or as the basis for adapted scales (Van Raaij \& Stoelhorst, 2008). Following these two conceptualizations, Tomaskova (2009) has gathered 26 models of market orientation measurements being developed after MARKOR and MKTOR. In deed, the two publications of Kohli \& Jaworski (1990) and Narver \& Slater (1990) have witnessed the widest diffusion and usage (Van Raaij \& Stoelhorst, 2008).

It becomes obvious that previous studies also perform the comparison between MARKOR and MKTOR, to find which one is more effective in explaining the level of market orientation.

The study of Gauzente (1999) conducted content analysis toward MARKOR and MKTOR. According to this study, MAKTOR is an organizational view of market orientation and develops an assessment of the potential of a company. In contrast, MKTOR is more customers oriented and exhibits a "check list" approach. MARKOR is being questioned about its statistical validity whereas is actually acknowledged by the authors themselves. The MKTOR's three components are fully operational, but the cultural componentof the definition of market orientation is overlooked in the measurement items.

Ellis (2006) performed a meta analysis of 56 studies in 28 countries, found stronger effect of market orientation in large, mature markets using MARKOR scale. Cano et al. (2004) agreed with this finding, but they underscored the strength of relationship between market orientation, and performance may be overstated when business performance was measured using subjective scales and understated when using objective scales.

MARKOR (Kohli \& Jaworski, 1990) was consisting of three components: (1) Generation of market intelligence (MOR_GEN), regarding the current and future needs of customers by the organization (2) Dissemination of the intelligence (MOR_DISS) to all departments in the organization, (3) Response of the organization (MOR_ROO) to the market intelligence.

Based on the above explanation, this study fixes the first hypothesis as,

H1: Market orientation gives positive and significant impact to the business performance of Indonesia Islamic banks.

\subsection{Islamic business ethics and business performance}

Ethics is concerning human conduct, with an emphasis on determining right and wrong, while business ethics is "the principles, values, and standards that guide behavior in the world of business (Ferrel et al, 2011: 5). The Business management is about correct decisions that affect a company, while ethics are all about assessing of how those decisions affect everything. Ethics are wider than management, because it concerns about the general context of the world, while management copes the context of the company (Hooker, 2003:). Therefore, ethical business conducts should become part of business strategy to accomplish higher and sustainable profit (Ferrel et al., 2011).

Islam is the religion that places the highest emphasis on ethical values in any aspects of Muslim's life, including business (Elmelki \& Ben Arab, 2009). Al Quran stated "Verily, this Al Quran guides to that which is most just and right and gives glad tidings to the believers..." [Al Quran 17:9]. The importance of ethical conducts is crystal clear as what Al Quran describes, "And verily, you (O Muhammad) are on an exalted standard of character." [Al Quran 68:4] and as Prophet Mohammed once said, I was sent to perfect good character" [Al Bukhari in Al Adab al Mufrad 
number 273]. In the view of ethical theory, argued that in Islamic teaching, ethics is a "Devine command", meaning all of the aspects about ethics have been detailed by divine text (Al Quran and Sunna) (Al-Aidaros et al.,2013)

Islamic teaching requires that business must be done in a way in which one neither be a loser nor greedy (Hussnain, 2011: 101). The objective of Islamic business ethics is to accomplish value-maximization based on equity and justice for the wider welfare of the society (Saeed et al., 2001: 138). According to Islamic finance scholars, the world has faced several global financial crises because of failed morality, manifested in forms of greed, exploitation and corruption (Is'haq 2012: 3-4). Therefore, the call for clearly formulated Islamic business ethics is urged (Abeng, 1997: 49).

Islamic banks are built subject to Islamic law based on Al Quran and Sunna (Van Schaik, 2001: 46). Thus, the implementation of Islamic business ethics in its business conducts is a mandatory.

In deed, Islamic banking is a relatively new industry, for example, in Malaysia it was started in 1988 (Ariff, 1988), while in Indonesia it began in 1991. The industry has shown rapid growth but the market growth is from a small base. Whereby, the industry is still in a formative and far from mature (Standard \& Poor, 2014). The businesses of Islamic banks are based on some basic principles (Elmelki \& Ben Arab (2009, 126), which are:

(i) The prohibition of taking or receiving interest (Riba), since Riba is rewarding people without involvement not participation in the risks of the projects financed, so the Islamic teaching considers this as violation to the principle of social justice.

(ii) The ban on unlawful assest acquiring from the the industries of tobacco, alcohol, gambling, drugs, hazardous products, pork or anything else that the Islamic law will classify as the prohibited or sinful activities (haram).

(iii) Prohibition on any transactions involving speculation or gambling (maysir), include any excessive ambiguity in transactions or contracts.

(iv) Any financial transaction should be based on a tangible, identifiable underlying asset.

Table 1 give highlighted comparison between conventional bank and Islamic bank.

\begin{tabular}{|c|c|c|}
\hline \# & Conventional Bank & Islamic Banks \\
\hline 1. & Based on fully man made laws. & $\begin{array}{l}\text { Based on Devine (Islamic) law (Quran and } \\
\text { Sunna) }\end{array}$ \\
\hline 2. & $\begin{array}{l}\text { The rate of interest (riba) is determined in } \\
\text { advance. }\end{array}$ & $\begin{array}{l}\text { Interest is not allowed but promotes risk sharing } \\
\text { between capital providers (investor) and funds } \\
\text { users (entrepreneur). }\end{array}$ \\
\hline 3. & It may maximize profit without any restriction. & $\begin{array}{l}\text { Islamic law set restrictions in the effort of } \\
\text { maximizing profit }\end{array}$ \\
\hline 4. & Charity is optional & $\begin{array}{l}\text { Islamic charity (zakat) is a mandatory, aside of } \\
\text { taxes obligation. }\end{array}$ \\
\hline 5. & $\begin{array}{l}\text { Lend money and getting repayment plus interest } \\
\text { without involvement in the business. }\end{array}$ & $\begin{array}{l}\text { Participation in partnership business is the } \\
\text { fundamental function of the Islamic banks. }\end{array}$ \\
\hline 6. & $\begin{array}{l}\text { It can charge additional money (penalty and } \\
\text { compounded interest) }\end{array}$ & $\begin{array}{l}\text { It has no provision to charge any extra money } \\
\text { from the defaulters. }\end{array}$ \\
\hline 7. & $\begin{array}{l}\text { Depend on the bank owners, no obligation to } \\
\text { ensure growth with equity. }\end{array}$ & $\begin{array}{l}\text { Since have orientation to the public interest, } \\
\text { growth with equity is important. }\end{array}$ \\
\hline
\end{tabular}


because interest is allowed. by Islamic law.

\begin{tabular}{|c|c|}
\hline $\begin{array}{l}\text { Table } \\
\text { cont. }\end{array}$ & \\
\hline 9. & $\begin{array}{l}\text { Fixed income from lending, so the expertise in Sharing profit and loss concept require Islamic } \\
\text { project appraisal and evaluations is less banks to pay greater attention in project appraisal } \\
\text { important. }\end{array}$ \\
\hline 10 . & $\begin{array}{l}\text { It gives greater emphasis on credit-worthiness of It gives greater emphasis on the viability of the } \\
\text { the clients. } \\
\text { projects. }\end{array}$ \\
\hline 11. & $\begin{array}{l}\begin{array}{l}\text { It can be as creditor and debtors in relation to its It can be as partners, investors and trader, buyer } \\
\text { clients. } \\
\text { and seller. }\end{array}\end{array}$ \\
\hline 12. & $\begin{array}{l}\text { It gives guarantee for deposit account based on } \\
\text { al-wadiah (keeper and trustee) principle, but not } \\
\text { for under mudarabah (risk sharing) principle. }\end{array}$ \\
\hline
\end{tabular}

Sources: Adapted from Rahman (2007)

In the precedent studies, the scholars have developed the construct of Islamic business ethics, using different viewpoints, such as from the view of Islamic bank or financial institution (e.g. Saidi, 2009; Gait \& Worthington, 2007; Nasution, 2009; Adebayo \& Hassan, 2009), from marketing view (Saeed et al., 2001; Ali, 2011), from general management point of view (Rice 1999; Muhammad et al. 2008; Is'haq 2012) and from leadership (Arslan, 2008; Abeng, 1997).

Following Widana et al. $(2014 ; 2015)$, there are seven dimensions of Islamic Business Ethics relevance to Islamic banks operations as synthesis of conceptualization being derived from pervious studies. These seven dimensions are proxy to Islamic ethics for business, since the limitation of the researchers to interpret comprehensively and irrevocably about the teaching of Al Quran and Sunna. These seven dimmensions of Islamic business ethics are:

(i) Unity of God (IBE_UNITY) means the unity of all aspects of life in accordance with God's will (Adebayo \& Hassan, 2013; Arslan, 2008; Asutay, 2007: Badawi, 2001; Rice, 1999; Wilson, 2006). Nasution (2009) added that unity principle brings faiths and attitudes all together as worship (ibadah);

(ii) Benevolence (IBE_BEN) means giving benefits to other persons with fineness and manumits (Muhammad et al., 2008), avoiding self-interest principle (Arslan, 2008). It reveals virtuousness, kindness, and incorporates mercy, fairness, compassion, tolerance and attentiveness (Ali, 2011);

(iii) Equilibrium (IBE_EQUIL) means maintaining balance between the present needs and the future (Asutay, 2007), to avoid greed, unscrupulousness and disregard for the rights or needs of others (Rice, 1999);

(iv) Justice and Equity (IBE_JUST) means just dealing for strengthening wider welfare of the society (Saeed et al., 2001; Ali, 2011). In this regard, equity, justice and fairness are frequently used with same meaning (Khan \& Thaut, 2008);

(v) Sincerity (IBE_SINC) means to the truth in word and act, honesty of intention, free from false pretense (Muhammad et al., 2008: 34). It also means the attitude to be friendly, modest and humble and no discrimination (Muhammad et al., 2008; Rice, 1999);

(vi) Trusteeship (IBE_TRUSTEE) means the view that God is the ultimate owner of universe and mankind as His vicegerents (khalifah) (Adebayo \& Hassan, 2013). Thus, people are required to comply with the legitimate manner in acquiring and utilizing the wealth for the benefit of whole society (Adebayo \& Hassan, 2013; Wilson, 2006); 
(vii) Responsibility (IBE_RESP) means that human being should be accountable for what his deeds (Arslan 2009), as the consequences as His vicegerents to define the word (Asutay, 2007; Nasution, 2009). Without responsibility, human equipped with free will can harm oneself, society and environment (Nasution, 2009).

Ethical business conducts affect to company in terms of creating higher and sustainable profit (Ferrel et al, 2011). Hence, unethical conducts may not be economically counterproductive, but they come with hidden risks that may have enormous and negative consequences for the company (Nguyen \& Wesley 2012). This view is supported by many empirical scholars showing evidence of positive relationship between business ethics and profitability (e.g. Verschoor 1997; Sirgy 2002; Berrone et al., 2007; Yau et al. 2000).

Therefore, the hypothesis about the connection between Islamic business ethics and business performance is:

$\mathrm{H}$ 2. The implementation of Islamic business ethics relates to business performance of Indonesia Islamic banks positively and significantly.

\subsection{Market orientation and Islamic business ethics}

The prior studies have not covered the inter relationship between market orientation and business ethics. In deed, several studies have discussed and given empirical evidence about the connection between market orientation as the antecedent of corporate social responsibility (CSR) (e.g. Brik et al, 2011; Arshad, 2012). Hence the concept of corporate social responsibility is distinctly different with the concept of business ethics, although these two commonly are used in almost interchangeably (Ferrell et al., 2011).

The business ethics is "the principles, values, and standards that guide behavior in the world of business" (Ferrell et al., 2011: 7), corporate social responsibility is "an organization's obligation to maximize its positive impact and minimize its negative impact on society" (Ferrell et al. 2011: 50). Corporate social responsibility comprised specific issues such as competition, shareholders, consumers, employees, community and environment (Dimitriades, 2007). Hence these two concepts are strongly related. In line with the argumentation of Grbac \& Loncaric (2009) that without being ethical inherently, an organization will be insincere and ineffective in its corporate social responsibility program and will fail to induce stakeholder engagement. Further Loumbeva (2008) explains that Business Ethics can direct managers and executives of a company in the right course to increases the reputation and continuous business development. So, business ethics will be drawn prior to corporate social responsibility.

Al Quran and Sunna have detailed ethics in Islamic teaching, including business ethics. Faith (iman) determined conscience and guided business activities, which in practice it meant to follow sharia law (Wilson, 2006). In Islam, ethics should govern economics, not the other way around (Rice, 1999).

Therefore, the hypothesis will be:

H3. Islamic business ethics will influence market orientation positively and significantly.

This study sees that market orientation may be as the mediator of the relationship between Islamic business ethics and business performance. Thus, this study arranges the fourth hypothesis is:

H4. Market orientation plays as the mediator of the relationship of Islamic Business Ethics and Business Performance of Indonesia Islamic banks.

\subsection{Business Performance measurement of Islamic bank}

Business performance is the result of business activities, in terms of financial or non-financial indicators. For financial indicator, measuring Islamic banks' performance from conventional performance ratio (such as ROA, ROE and Net Profit Margin) will not be sufficient. Evaluating Islamic banks' performance must be also assessed from their relative compliance with Islamic law principles (Kuppusamy \& Samudhram, 2010). The assessment should be referred to the social objectives of Islamic banks, otherwise errors and inconsistencies will be portrayed in the conclusions (Hasan, 2004). 
To be inlined with the objectives of Islamic banking, Mohammed et al. (2008) proposes the financial ratios in evaluating the performance, which are: (1) The aspect of education: Education grant/total income, Research expense/total expense, Training Expense/total expense and Publicity expense/total expense; (2) The aspect of justice establisgment: Profit/ total income, Bad debt/ total investment, Interest free income/ total income.;(3) The aspect of promoting the welfare: Net profit/ total asset, Zakat payment/ Net Income, Investment deposit/total deposit.

The above measurement may be difficult to be conducted due to the disclosure regulation or policy of Islamic banks' financial statements. In this regards, Kuppusamy \& Samudhram (2010) give alternative of mesurement of the performance of Islamic banks use a combined set of indicators (conventional and Islamic):

(1) Islamic ratios, consist of Islamic investment ratio (BPE_IVES) $=$ (Islamic Investment/[Islamic Investment and non-Islamic Investment]), Islamic income ratio $\left(B P E_{-} I C O M\right)=($ Islamic Income/[Islamic Income + non-Islamic Income $])$, and profit sharing ratio $($ BPE_PSR $)=([$ Mudarabah + Musharakah $] /$ Total Financing $)$;

(2) Conventional ratios, consist of: return on asset $\left(B P E_{-} R O A\right)$, return on equity, and profit margin ratio $\left(B P E_{-} P M A R\right)$

In the case of Indonesia Islamic banks, there are two categories i.e. "full flagged" Islamic commercial banks and "Islamic window" as the business unit in conventional banks (the Syariah Business Unit) (Indonesia Financial Services Authority, 2014). There is a difference format of financial data in the published financial reports of Islamic commercial banks and the Syariah Business Unit, e.g. the data of equity of Syariah Business Unit is not disclosed. Consequently, the indicator of return on equity (ROE) as mentioned by Kuppusamy \& Samudhram (2010) cannot be retrieved completely.

Kirca et al. (2005) mention that market orientation also affects to the sales volume. In banking, this indicator is equal to the revenue. In order to have a comparable indicator, this study uses the indicator of revenue growth (IBE_RGRO) an approach to sales volume, because Indonesia Islamic banks are varied in terms of assets size.

\section{Research and Methodology}

The study followed Churchill's (1979) framework in developing measurement, consisting some systematic stages.

\subsection{Generating Measurement Items}

This procedure involves two subsequent stages. The first stage is gathering items (instruments) form prior studies based on the literature review. The second stage is the assessment of face and content validity of the measurement items.

In populating instruments from previous studies, this study compiled 20 items of MARKOR (Kohli et al., 1993) to measure market orientation. Specifically for Islamic business ethics, this study develops original instrument consisting of 21 items, which are derived from the ethical values proposed by scholars in preceding conceptual studies. This was taken because of the lack of empirical study of Islamic Business ethics in banking. The questionnaires of this study are circulated in Indonesian language (Bahasa Indonesia) in order to obtain the same level of understanding among respondents. Thus before assessing face and content validity, all instruments being collected are translated from English to Bahasa Indonesia with some refinements to adjust with the local context. The procedure of translation is followed the recommendation of Forsyth et al. (2006).

The face and content validity assessment are conducted by the panel of experts, consisting of two experts in marketing and two top executives of Indonesia Islamic banks. The systematic steps in this stage are:

(i) All versions of instruments (in English and Bahasa Indonesia) are sent to the panel of expert;

(ii) The panel of experts evaluates the face validity and content validity, by rating each of the 41 instruments, using 3 point scales $(1=$ not at all, $2=$ somewhat, and $3=$ completely representative). This study assesses face and content 
validity by eliminating instruments being graded 1 (not all representative) by at least one member of the expert panel (Bearden et al., 1989). Upon accomplishment this step, all 41 items are considered representative and valid;

(iii) Performing pretest to ten potential respondents via interview to check their understanding to the questionnaire items, using the version draft in Bahasa Indonesia;

(iv) Final review and completion of questionnaire format, using 5 scales of Likert, i.e. 1 means strongly do not agree; 2 means do not agree; 3 means neutral; 4 means agree and 5 means strongly agree.

\subsection{The main survey procedure}

The present research focuses on the institution of Indonesia Islamic bank, but the data collection is compiled at individual level.

The total number of Islamic banks in Indonesia is 34 institutions, which consists of 11 Islamic commercial bank and 23 Shariah Business Unit (Indonesia Financial Services Authority, 2014). The locations of those banks are scattered throughout Indonesia. While in terms of size of assets and the number of branches are different greatly.

To resolve the hurdles of the objective condition of the target respondents, this study uses the method of cluster sampling as it is relatively easy to implement and cost effective (Malhotra, 2010). First, because of the number banks is limited, this study determines that all of 34 head offices of Islamic banks become sampling frame. Second, for the target respondents, the study implements systematic random sampling based on the staff names list. Third, the questionnaires are sent to target respondents through email, as it is self administered questionnaire format. All questionnaires are attached with introduction letter and recommendation letter from the Indonesia Islamic Banks Association.

\subsection{The collected data}

This study collects data from two sources. The data of market orientation and Islamic business ethics is gained from the response to the prepared questionnaires. The questionnaires are distributed during March-August 2013 to all bank for the total of 500 sets of questionnaires. At the end collection period, 184 responses from 22 Indonesia Islamic banks is received, representing $36.8 \%$ of response rate. Table 1 shows the profile of respondent.

For the data of business performance, this study gathers data from the published financial statement of each bank, for the date of 31 December 2013. These financial statements can be accessed publicly via the banks' web or Indonesia Financial Services Authority's web (www.bi.go.id).

Table 1. The profile of respondents

\begin{tabular}{|c|c|c|c|c|}
\hline$\overline{\#}$ & Profile & Description & Numbers & $\%$ \\
\hline \multirow[t]{4}{*}{1.} & \multirow{4}{*}{$\begin{array}{l}\text { Position } \\
\text { organization }\end{array}$} & the Senior management level & 54 & $29 \%$ \\
\hline & & Middle management level & 118 & $64 \%$ \\
\hline & & Low management level & 12 & $7 \%$ \\
\hline & & Total & 184 & $100 \%$ \\
\hline \multirow[t]{3}{*}{2.} & \multirow[t]{3}{*}{ Gender } & Male & 115 & $63 \%$ \\
\hline & & Female & 69 & $38 \%$ \\
\hline & & Total & 184 & $100 \%$ \\
\hline \multirow[t]{3}{*}{3.} & \multirow[t]{3}{*}{ Age } & Below 30 & 27 & $15 \%$ \\
\hline & & $30-45$ & 26 & $68 \%$ \\
\hline & & Above 45 & 31 & $17 \%$ \\
\hline
\end{tabular}




\begin{tabular}{|c|c|c|c|c|}
\hline & & Total & 184 & $100 \%$ \\
\hline \multirow[t]{4}{*}{4.} & Education & Post graduate & 47 & $26 \%$ \\
\hline & & Bachelor degree & 135 & $73 \%$ \\
\hline & & Below undergraduate & 2 & $1 \%$ \\
\hline & & Total & 184 & $100 \%$ \\
\hline \multirow[t]{3}{*}{5.} & Religion & Islam & 178 & $97 \%$ \\
\hline & & Others & 6 & $3 \%$ \\
\hline & & Total & 184 & $100 \%$ \\
\hline
\end{tabular}

\subsection{Measurement Purification}

The analysis eliminates the inconsistent items as defined by the construct (Churchil, 1979), employs two stages of test. The first stage screens using two tools, i.e. the item to total correlation must above 0.35 and total Cronbach's Coefficient Alpha should be more than 0.5 (Bearden et al., 200). The second stage is using SmartPLS at dimension level, whereby the dimensions having factor loading larger than 0.50 and Cronbach's Coefficient minimum of 0.60 are taken as reliable measurement. All items pass this test.

\subsection{Assessment Reliability and Validity}

Cronbach's coefficient alpha must be combined with the composite reliability, to avoid underestimation of the internal consistency reliability of latent variables in PLS path models. In this regard, the composite reliability must exceed the threshold value of 0.7 (Henseler et al., 2009).

For the assessment of validity, two types of validity are used, i.e. the convergent validity and discriminant validity. The convergent validity measures the variance shared by a variable and its indicator, whereas the average variance extracted (AVE) should be greater than 0.50 (Henseler et al., 2009).

Table 2. Cronbach's coeffisient alpha, composite reliability and AVE

\begin{tabular}{llll}
\hline Construct & Cronbach's Alpha & Composite Reliability & AVE \\
\hline BPE & 0.906306 & 0.92894 & 0.687564 \\
\hline IBE & 0.936911 & 0.946303 & 0.717245 \\
\hline MOR & 0.924571 & 0.952365 & 0.869641 \\
\hline
\end{tabular}

The test of discriminant validity is ensuring the uniqueness of the concept to other concepts of measurement. The Fornell-Larcker criterion is adopted, which the square root of AVE is greater than the corresponding off-diagonal correlations (Henseler et al., 2009) and cross-loadings whereas the loading of each indicator must be greater than all of its cross-loadings (Chin, 1998). Table 3 and Table 4 show the result of Fornell-Larcker test and cross loading analysis consecutively. 
Table 3. The Fornell-Larcker test

\begin{tabular}{llll}
\hline Construct & BPE & IBE & MOR \\
\hline BPE & 1 & 1 & \\
\hline IBE & 0.84800 & 0.86604 & \\
\hline MOR & 0.97603 & \\
\hline Construct & \multicolumn{1}{|c|}{} & \\
\hline BPE & 0.829 & \\
\hline IBE & 0.847 & \\
\hline MOR & 0.933 &
\end{tabular}

Table 4. Cross loading analysis

\begin{tabular}{|c|c|c|c|}
\hline & IBE & MOR & BPE \\
\hline IBE_BEN & 0.93768 & 0.66387 & 0.68022 \\
\hline IBE_EQUIL & 0.79346 & 0.49607 & 0.48591 \\
\hline$\overline{\mathrm{IBE} \_J U S T}$ & 0.92309 & 0.64039 & 0.63230 \\
\hline$\overline{\mathrm{IBE} \_ \text {RESP }}$ & 0.85423 & 0.51465 & 0.53346 \\
\hline$\overline{\mathrm{IBE} \_S I N C}$ & 0.94596 & 0.79482 & 0.91102 \\
\hline IBE_TRUSTEE & 0.88497 & 0.57528 & 0.55793 \\
\hline$\overline{\text { IBE_UNITY }}$ & 0.93126 & 0.71775 & 0.88770 \\
\hline$\overline{\mathrm{MOR} \_\mathrm{COO}}$ & 0.95795 & 0.88979 & 0.86122 \\
\hline MOR_DIS & 0.73892 & 0.95396 & 0.90684 \\
\hline$\overline{\text { MOR_GEN }}$ & 0.70899 & 0.96125 & 0.95245 \\
\hline$\overline{\text { BPE_ICOM }}$ & 0.68910 & 0.75769 & 0.78824 \\
\hline BPE_IVES & 0.86581 & 0.90797 & 0.92456 \\
\hline$\overline{\text { BPE_PMAR }}$ & 0.74980 & 0.83676 & 0.91162 \\
\hline$\overline{\text { BPE_PSR }}$ & 0.52640 & 0.68961 & 0.76072 \\
\hline BPE_RGRO & 0.64165 & 0.71955 & 0.80145 \\
\hline$\overline{\text { BPE_ROA }}$ & 0.70446 & 0.79376 & 0.88201 \\
\hline
\end{tabular}

\subsection{Test of Hypotheses}

Structural model specifies the relationship between latent variables. SmartPLS is used to produce the path coefficient $(\beta)$ and the coefficient of determination $\left(\mathrm{R}^{2}\right)$ for each variable of the model. Bootstrapping procedure is 
applied to produce standard deviation and t-statistics. Figure 1 presents the conceptual model being employed by this study and the result of assessment $\beta$ and $\mathrm{R}^{2}$.

Chin (1998) recommends that $\beta$ range between 0.20 to 0.30 would explain $50 \%$ or more of the variance of the latent variable or model. While, $t$-values which is greater than 1.96 indicate a significant level of $0.05(\mathrm{p}<0.05)$, over than 2.58 means a significant level of $0.01(p<0.01)$ and more than 3.26 presents a significant level of $0.001(p<0.001)$. Further, regarding $\mathrm{R}^{2}$, if the value is above 0.67 describe substantial, higher than 0.33 mean moderate and below 0.33 but above 0.19 explain weak determination.

$\mathrm{H} 1$ is accepted because $\beta$ is 0.8338 and the $\mathrm{t}$-value is $2.677221(\mathrm{p}<0.05)$, meaning market orientation gives positive and significant impact to the business performance of Indonesia Islamic banks. This association is explaining more than $50 \%$ of the variance of business performance of the model.

In regards with $\mathrm{H} 2$, this study finds that $\beta=0.124468$ and $\mathrm{t}$-value is 0.484258 which is less than treshold 1.96. Thus, $\mathrm{H} 2$ is partially accepted, whereby Islamic business ethics positively relates to business performance, yet the relationship is not significant.

As expected, H 3 is asserted as $\beta=0.866044$ and $t$-value is 50.667743 ( $p<0.001)$, supporting that Islamic business ethics influaces market orientation positively and significantly.

The analysis of $\mathrm{R}^{2}$ of the inner model show that endogenous latent variables of market orientation $\left(\mathrm{R}^{2}=0.8334\right)$ as well as business performance $\left(\mathrm{R}^{2}=0.8465\right)$ give substantial determination. Figure 1 show the illustration of the result of test of hypothesis.

Figure 1. The conceptual model and the result of test of hypothesis

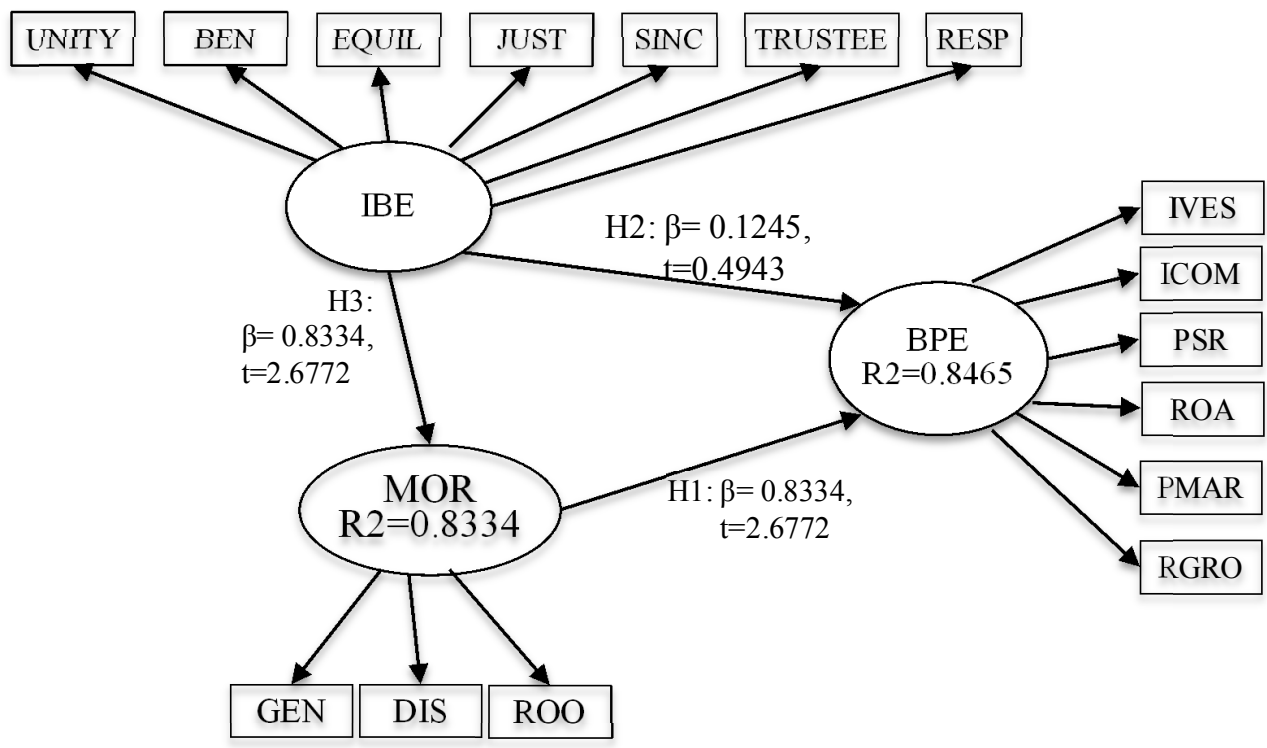

Regarding the the assessment of mediating role of market orientation $(\mathrm{H} 4)$, this study takes the procedure as recommended by Baron \& Kenny (1986), as shown by Table 6 . This study finds that market orientation mediates the relationship between Islamic business ethics and business performance, yet it is not significant $(\beta=0.07153$ and $\mathrm{t}$-value is 0.557786$)$. 
Table 5. The mediating test of market orientation

\begin{tabular}{|l|l|l|l|l|}
\hline Path & Total effect & $\begin{array}{l}\text { Standard } \\
\text { Deviation }\end{array}$ & t-Statistics & Significance \\
\hline IBE $\rightarrow$ MOR $\rightarrow$ BPE & 0.07153 & 0.128239 & 0.557786 & Not signifikan \\
\hline
\end{tabular}

\section{Discussion}

This study carefully follows the procedure as being set by research methodology, to achieve the objective, which is verifying the inter relationship among Islamic business ethics, market orientation and business performance of Indonesia Islamic banks.

Islamic banking in Indonesia has begun since 1991 through the establishment of Bank Muamalat Indonesia. According data of Indonesia Financial Services Authority (2013), in the last 10 years the pace of growth of Indonesia Islamic banks have been impressive, i.e. 29\% compared to $10 \%$ of conventional banks. Yet, profitability of Islamic banking (2012 ROA=1.94\% and PMAR=2.04\%; in $2013 \mathrm{ROA}=2.00 \%$ and PMAR $=2.62 \%$ ) is lower than conventional banking (2012 $\mathrm{ROA}=3.11 \%$ and PMAR $=5.49 \% ; 2013 \mathrm{ROA}=3.08 \%$ and $\mathrm{PMAR}=4.89 \%)$. In addition, Islamic banks only possess around $5 \%$ of the market share in term of total assets of Indonesia banking.

This study confirms the previous studies that market orientation gives positive impact to business performance. This is consistent with the data of Indonesia Financial Services Authority (2014), indicates that Indonesia Islamic banking is growing considerably. Market orientation in deed is an offensive strategy (Tse et al., 2004) to capture bigger market share. In line also with Gounaris \& Avlonitis (2001) who state that market orientation a broad recipe of company practices.

In contrast with the underlying literatures, Islamic business ethics influences to business performance but not substantial. The explanation of this phenomenon needs deeper analysis to market and industry of Indonesia Islamic as well.

From the Indonesia banking's market view, there are three segments of customers, i.e. (i) Islamic bank loyalists, who are strong committed Muslims and will loyal to the Islamic banks in any conditions, (2) conventional bank loyalists, who will not be interested to have transactions with Islamic banks, (3) the floating mass segment that may be Muslim or non-Muslim and will be rational and fairly compare Islamic banks versus conventional banks before choosing a bank.

It seems that Islamic banks expand its market from loyalist segment to floating mass segment. Unfortunately, Islamic banks must cut its pricing to capture more new customers. This is explained why the profitability of Islamic banks is lower than conventional banks. The scholars in Islamic banking have actually warned about this phenomenon, e.g. Wilson (2005) and Saidi (2009) who have argued that Islamic banks should rely on the unique quality of the services and products rather than pricing to win the competition against conventional banks.

The other finding of this study is that Islamic business ethics implementation is precedent of market orientation. This is new evidence to broaden the literature regarding business ethics and market orientation, whereby these two constructs have strong relationship. However, this study also reveals that market orientation does not fully mediate the connection between Islamic business ethics and business performance. It means that although higher level of Islamic business ethics implementation will augment market orientation of the company, Islamic business ethics still need other manifestation to become significant factors in contributing to companies' business performance.

The scholars through two conceptual papers, give indication what manifestation that ethics will be able to give positive impact to the performance. Hassan et al. (2008) argued that business ethics should be incorporated into the marketing strategy of company in order to accomplish the customer satisfaction. As being defined at the outset, that market orientation will also associate positively to the customer satisfaction (Narver \& Slater, 1990). While Widana 
et al. (2015) explained that the implementation of relationship marketing will play as the mediator of the connection between Islamic business ethics and business performance. Accordingly, these linkages must be elaborated in the future study by stipulating empirical data.

\section{The managerial implication}

Become market oriented is the correct path for Indonesia Islamic banks in expanding its market. Hence, to keep growing without reducing profitability, Indonesia Islamic banks must be able to create distinctive features. In this regards, Islamic business ethics must be embedded in the company strategy as well in the products and services in such a way that customers will enjoy the benefit directly. In the global growing trend of customers to select banks which shows good ethical conducts, as happen today (Carrasco, 2006), Islamic bank should be in front the row. As indicated by Saidi (2008), Islamic banks have all aspects to be called as ethical banks.

\section{Conclusion}

This study replicates the earlier studies in confirming the relationship between market orientation and business performance in the context of Indonesia Islamic banks. As the contribution to market orientation literatures, this study adds the construct of Islamic business into the model, parallel with the recommendation prior studies that strategic action must be included in the model of relationship between market orientation and business performance.

This study gives another evidence that market orientation influences business performance. While as the major contribution of this study to the body of market orientation literatures, that Islamic business ethics have positive association with market orientation. Further, this study observes that for Indonesia Islamic bank the Islamic business ethics provides impact to business performance, but not significant. Lastly, market orientation plays the role as a mediator of the connection between Islamic business ethics and business performance, yet this role is not significant either.

This study opines based on the findings that Indonesia Islamic banks are expanding its market from the loyalist segment to the floating mass segment. In deed, market orientation is the correct strategy. However, there is indication that Islamic banks suffer because of the thinner margin compare to conventional banks. In this regards, Islamic business ethics should be implanted in product or service to become distinctive features to win the competition.

\section{Limitations and future directions}

In a rapidly evolving industry such as banking, using discrete data approach may not describe the real condition over time, regarding the impact of strategic actions to various levels of business performance. Thus for future studies, it is recommended to use longitudinal data to get more representative information and condition.

This study asserts that market orientation relates to creation of higher business performance. Hence, how fineness market orientation in Islamic banks is not covered. In confronting the competition with the holders of much bigger market shares i.e. the conventional bank, it is important to compare the level of market orientation between two different type of banks. The future studies can elaborate this dissimilarity.

This study recommends Indonesia Islamic bank to develop the unique features of products and services, which is embedded with Islamic business ethics. The future studies may focus on this issue, particularly from the view of customers.

\section{References}

Al Quran. English translation of the meanings and commentary by Ali, A.Y. (1987), Saudi Arabia: Presidency of Islamic Researches, IFTA, Call and Guidance, King Fahd Holy Quran Printing Complex. 
Al Bukhari. Al Adab al Mufrad. Accessed October 12, 2014. http://ebooks.worldofislam.info/ebooks/Hadith\%20\&\%20Sunnah/Adab\%20Al-Mufrad\%20\%20Imam\%20Bukhari.pdf

Abeng, T. (1997). Business ethics in Islamic context: perspective of a muslim business leader. Business Ethics Quarterly, 7(3), 47-54.

Adebayo, I., \& Hassan, M. (2013). Ethical principles of Islamic financial institutions. Journal of Economic Cooperation and Development, 34(1), 63-90.

Al-Aidaros, A., Shamsudin, F.M. \& Idris K.M. (2013). Ethics and ethical theories from an Islamic perspective, International Journal of Islamic Thougt, 4, 1-13.

Ali, A. J. (2011). Islamic ethics and marketing. In Sadikci, O \& Rice, R. (eds). Handbook of Islamic Marketing, (pp. 17-34). UK: Edward Elgar Publishing Limited.

Ariff, M. (1988). Islamic Banking. Asian-Pacific Economic Literature, 2(2), 48-64.

Arslan, Z. (2009). Islamic business ethics and its impact on strategic business decision making process of muslims. Simon Fraser University. Accessed October 11, 2014. http://summit.sfu.ca/item/770

Arshad, R.,Mansor, S.M.,Othman, R. (2012). Market orientation, firm performance and the mediating effect of corporate social responsibility, Journal of Applied Business Research, 28, 5, 851-860.

Asutay, M. (2007). A political economy approach to Islamic economics: systemic understanding for an alternative economic system. Kyoto Bulletin of Islamic Area Studies, 1(2), 3-18.

Indonesia Financial Services Authority. (2014). Statistics of Indonesia banking December 2013. Accessed August 10, 2014. http://www.bi.go.id/id/statistik/perbankan/indonesia/Pages/SPI_1213.aspx

Baron, R. M. \& Kenny, K.A. (1986), Moderator-mediator variables distinction in social psychological research: Conceptual, Strategic, and Statistical Considerations. Journal of Personality and Social Psychology, 51 (6), 1173-82.

Bearden, W., Hardesty, D.M \& Rose, R. (2001). Consumer self-confidence: refinements in conceptualisation and measurement. Journal of Consumer Research, 28 (1), 121-136.

Bearden, W. O., Netemeyer, R.G., \& Teel. J.E. (1989). Measurement of Consumer Susceptibility to Interpersonal Influences. Journal of Consumer Research, 15(4), 473-81.

Berrone, P., Surroca, J. \& Tribo, J.A. (2007). Corporate ethical identity as a determinant of firm performance: a test of the mediating role of stakeholder satisfaction. Journal of Business Ethics, 76(1), 35-53.

Brik, A.B., Rettab, B., \& Mellahi, K. (2011). Market orientation, corporate social responsibility, and business performance, Journal of Business Ethics, 99, 307-324.

Cano, C., Carrill, F. A., \& Jaramillo, F. (2004), A meta-analysis of the relationship between market orientation and business performance: evidence from five continents, International Journal of Research in Marketing, 21, 179-200.

Carrasco, I. (2006). Ethics and banking. International Advances in Economic Research, 12(1), 43-50.

Chin, W. W. (1998). The partial least squares approach to structural equation modeling. In Marcoulides, G. A. (Ed), Modern Methods for Business Research (pp. 295-336). Mahwah, NJ, US: Lawrence Erlbaum Associates.

Churchill, G.A. (1979). A Paradigm for developing better measures of marketing constructs. Journal of Marketing Research (pre-1986), 64-73. 
Dimitriades, Z.S. (2007). Business ethics and corporate social responsibility in the e-economy: A Commentary, Electronic Journal of Business Ethics and Organization Studies. Accessed 12 December, 2014.

Ellis, P. D. (2006). Market orientation and performance: a meta-analysis and cross-national comparisons, Journal of Management Studies, 43(5), 1089-1106.

Elmelki, A., \& Ben Arab, M. (2009). Ethical investment and the social responsibilities of the Islamic banks. International Business Research, 2(2), 123-130.

Ferrel, O.C, Fraedrich, J., \& Ferrell, L. (2011). Business ethics, ethical decision making and cases (8th Edition). USA: South-Wester Cengage Learning.

Forsyth, B.H., Kudela, M.S., Levin, K., Lawrence, D., \& Willis. G.B. (2007). Methods for translating an english-language survey questionnaire on tobacco use into Mandarin, Cantonese, Korean, and Vietnamese. Field Methods, 19 (3), 264-283.

Gauzente, C. (1999). Comparing market orientation scales: a content analysis. Marketing Bulletin, 10, 7682.

Gounaris, S. P. \& Avlonitis, G.J. (1997). Company and market correlates of marketing orientation development: an empirical investigation, Paper presented at the 26 EMAC Conference, Warwick, 20-23 May, 536555 .

Grbac, B. \& Loncaric, D. (2009). Ethics, social responsibility and business performance in a transition economy, EuroMed Journal of Business, 4 (2), 143-158.

Hassan, A., Chachi, A., \& Latiff, S. A. (2008). Marketing Ethics and Its Impact on Customer Satisfaction in the Islamic Banking Industry. Journal of King Abdulaziz University: Islamic Economics, 21(1), 27-46.

Hasan, Z. (2004). Measuring efficiency of Islamic banks: criteria, methods, and social priorities. Review of Islamic Economics, 2, 5-30.

Henseler, J., Ringle, C. M \& Sinkovics, R.R. (2009). The use of partial least squares path modeling in international marketing. Advances in International Marketing, 20, 277-319.

Hooker, J. (2003). Why business ethics? Carnegie Mellon University. Accessed April 25th, 2014. http://wpweb2.tepper.cmu.edu/ethics/whybizethics.pdf.

Hult, G. T. M., Ketchen Jr, D. J. \& Slater, S.F. (2005), Market orientation and performance: an integration of disparate approaches. Strategic Management Journal, 26, 1173-1181.

Hussnain, S. A. (2011). What is Islamic marketing. Global Journal of Management and Business Research, 11(11). Accessed February 28, 2014. https://globaljournals.org/GJMBR_Volume11/10. What-Is-IslamicMarketing.pdf.

Is'haq, A. Y. (2012). Does ethics matter in corporate business management from view point of Islam? Kuwait Chapter of Arabian Journal of Business and Management Review, 2(2), 1-9.

Karim, A. A. \& Afiff, A. A. (2005). Islamic banking consumer behavior in Indonesia: A Qualitative Approach. Paper is presented at the 6th International Conference on Islamic Economics and Finance, Jakarta, November 21-24.

Khan, A. A. \& Thaut, L. (2008). An Islamic perspective on fair trade. Islamic Relief Worwide, 1-13. Accesed Februari 28, 2014. http://www.Islamic-relief.com/indepth/downloads/Islam_and_Fairtrade.pdf

Kirca, A. H., Jayachandran, S., \& Bearden, W. O. (2005). Market orientation: a meta-analytic review and assessment of its antecedents and impact on performance. Journal of Marketing, 69, 24-4. 
Kohli, A. K., \& Jaworski, B. J. (1990), Market orientation: the construct, research prepositions and managerial implication, Journal of Marketing, 54, 1-18.

Kohli, A. K., \& Jaworski, B. J. Kumar, A., (1993) MARKOR: a measure of market orientation, Journal of Marketing Research, 30(4), 467-477.

Kuppusamy, M., Saleh, A.S., \& Samudhram, A. (2010). Measurement of Islamic banks performance using a shariah conformity and profitability model. Review of Islamic Economics, 13, 35-48.

Loumbeva, N. (2008). Business ethics as an enabler of corporate social responsibility: an organizational learning knowledge management approach to participatory business ethics, University of Geneva. Accessed October 11,2014. http://www.unige.ch/formcont/CSR/Thesis08_Loumbeva.pdf

Malhotra, N. K. (2007). Marketing research: an applied orientation (5th ed.). Upper Saddle River, NJ: Pearson Prentice Hall.

Matsuno, K., Mentzer, J. T. \& Rent, J. O. (2002). A conceptual and empirical comparison of three market orientation scales, Journal of Business Research, 58, 1-8.

McKitterick, J.: 1958, What is the marketing management concept, in F. Bass (ed.), The Frontiers of Marketing Thought and Science. Chicago, IL: American Marketing Association.

Mohammed, M.O., Razak, D. A., \& Taib F. M. (2008). The Performance Measures of Islamic Banking Based on the Maqasid Framework, Paper is presented at the IIUM International Accounting Conference (INTAC IV), Putra Jaya, Malaysia, June 25, 1-17.

Muhammad, M. Z., Ilias, A. Ghazali, F.M., Abdullah, R.C., \& Amin, H. (2008). An analysis of Islamic ethics in small and medium enterprises (SMEs). Unitar E-Journal, 4(1), 48-58.

Narver, J. C \& Slater, S. F (1990), The effect of market orientation on business profitability, Journal of Marketing, 54(4), 20-35.

Nasution, M.E. (2009). Islamic spirit and morale in economics. Journal of International Development and Cooperation, 15(1-2), 113-24.

Nguyen, A. \& Cragg. W. (2012). Interorganizational favor exchange and the relationship between doing well and doing good. Journal of Business Ethics, 105, 53-68.

Olavarrieta, S. \& Friedmann, R. (2008). Market orientation, knowledge-related resources and firm performance, Journal of Business Research 61(6), 623-630.

Rahman, U. H. Z. (2007). Differences Between Islamic Bank and Conventional. Accessed May 2, 2011. Http://zaharuddin.net/index.php?option=com_content\&task=view\&id=297\&Itemid=72

Rice, G. (1999). Islamic ethics and the implications for business. Journal of Business Ethics, 18, 345-358.

Saeed, M., Ahmed, A. U., \& Mukhtar, S.M. 2001. International marketing ethics from an Islamic perspective: a value-maximization approach. Journal of Business Ethics, 32(2), 127-142.

Saidi, T. A. (2009). Relationship between ethical and Islamic banking systems and its business management implications. South African journal of Business Management, 40(1), 23-49.

Sirgy, M. J. (2002). Measuring corporate performance by building on the stakeholders model of business ethics. Journal of Business Ethics, 35(3), 143-162.

Standar \& Poor. (2014). Islamic Finance Outlook 2014 Edition. Accesed October 13, 2014. http://www.standardandpoors.com/spf/upload/Ratings_EMEA/IslamicFinanceOutlook_2014.pdf 
Tomaskova, I.E. (2009) The current methods of measurement of market orientation. European Research Studies, 12(3), 135-150.

Tse, A.C.B., Sin, L. Y. M., Yau, O. H. M., Lee, J. S. Y., \& Chow, R. (2004). A firm's role in the marketplace and the relative importance of market orientation and relationship Marketing Orientation. European Journal of Marketing, 38(9), 1158-1172.

Van Raaij, E. M., \& Stoelhorst, J. W. (2008), The implementation of a market orientation a review and integration of the contributions to date, European Journal of Marketing, 42(11/12), 1265-1293.

Van Schaik, D. 2001. Islamic banking. The Arab Bank Review, 3(1), 45-52.

Verschoor, C. C (1998) A study of the link between a corporation's financial performance and its commitment to ethics, Journal of Business Ethics 17(13), 1509-1516.

Widana, G.O., Wiryono, S.K., Purwanegara, M.S., \& Toha, M. (2015). Exploring the impact of Islamic business ethics and relationship marketing orientation on business performance: the Islamic banking experience, Asian Academic of Management Journal, 20(1).

Widana, G.O., Wiryono, S.K., Purwanegara, M.S., \& Toha, M. (2014). Measuring Islamic Business Ethics Within Indonesia Islamic Banks. Global Journal At Thafaqah, 4 (2), 1-11.

Wilson, R. (2005). Parallels between Islamic and ethical banking. Journal of Islamic Banking and Finance, 22(3), 1-12.

Wilson, R. (2006). Islam and business. Thunderbird International Business Review, 48 (1), 109-123.

Zhou, K. Z., Li, J. J., Zhou, N., \& Su, C. (2008). Market orientation, job satisfaction, product quality, and firm performance: evidence from China. Strategic Management Journal, 29, 985-1000. 